\title{
Mobile-assisted Language Learning (MALL) for ESL Learners: A Review of Affordances and Constraints
}

\author{
Harwati Hashima, Melor Md. Yunusa ${ }^{a}$, Mohamed Amin Embi ${ }^{b}$, Nor Azwa Mohamed Ozira \\ ${ }^{a}$ Fakulti Pendidikan, Universiti Kebangsaan Malaysia, 43600 UKM, Bangi Selangor, Malaysia \\ ${ }^{b}$ Pusat Pengajaran dan Teknologi Pembelajaran, Universiti Kebangsaan Malaysia, 43600 UKM, Bangi Selangor, Malaysia
}

*Corresponding author: melor@ukm.edu.my

\begin{abstract}
Nowadays, mobile technology is changing the landscape of language learning and is seen as the next frontier being researched for its potential in enhancing the teaching and learning of English language. The portability of mobile devices is believed to bring new methods that can shape learning styles and pedagogies which could become more personalised and allow learners to learn on the move; thus, enhance English language teaching and learning. This creates the potential for significant change in the teaching and learning of English as Second Language (ESL). Taking mobile learning as the setting within which developments in Mobile-assisted Language Learning (MALL) may be understood, this paper offers reflections on what Mobile-assisted Language Learning (MALL) has potentially offered and the constraints that might be faced by the English as Second Language (ESL) learners when using MALL. Above all, it was a challenging issue to cover learning tasks by using a mobile device particularly in learning English as Second Language (ESL). Nevertheless, mobile devices which are popular among students are motivational tools to be used in education as well as various learning activities. This was proven by many researchers who have shown the positive outcomes. Hence, we should admit that mobile devices are finding their way into classrooms in the student's pockets, and we have to ensure that educational practice can include this mobile technology in effective and productive ways particularly for English as Second Language (ESL) learning.
\end{abstract}

Keywords: Mobile-assisted language learning (MALL); English as Second Language (ESL); ESL learners; ESL learning; mobile devices

\begin{abstract}
Abstrak
Pada ketika ini, perkembangan pesat di dalam teknologi telah mengubah landskap pembelajaran bahasa dan dilihat sebagai bidang yang perlu dikaji potensinya dalam meningkatkan pengajaran dan pembelajaran Bahasa Inggeris. Kemudahan alat peranti mudahalih terbukti menjanjikan kaedah baru yang boleh membentuk gaya pembelajaran dan pedagogi yang lebih bersifat personal dan memberi ruang kepada pelajar untuk mempertingkatkan pembelajaran bahasa Inggeris. Ini mewujudkan potensi untuk perubahan yang signifikan di dalam pengajaran dan pembelajaran Bahasa Inggeris sebagai Bahasa Kedua. Dengan mengambil kira persekitaran di mana pembelajaran bahasa berbantukan alat peranti mudahalih boleh difahami, kertas kerja ini membincangkan refleksi kepada potensi kebaikan yang ditawarkan oleh pembelajaran bahasa berbantukan alat peranti mudahalih, dan juga kekangan yang mungkin dihadapi oleh pelajar-pelajar Bahasa Inggeris sebagai bahasa kedua sekiranya menggunakan pembelajaran bahasa menggunakan alat peranti mudahalih. Secara keseluruhannya, ia adalah satu isu mencabar yang meliputi tugasan yang meluas dalam pembelajaran bahasa menggunakan alat peranti mudahalih terutamanya dalam pembelajaran Bahasa Inggeris sebagai bahasa kedua. Walau bagaimanapun, alat peranti mudahalih yang popular dalam kalangan pelajar adalah alat yang boleh meningkatkan motivasi dalam pendidikan dan juga digunakan di dalam pelbagai aktiviti pembelajaran. Ini telah dibuktikan oleh kebanyakan penyelidik yang telah menunjukkan hasil yang positif. Maka, harus diakui bahawa alat peranti mudahalih dan pelajar tidak boleh dipisahkan, oleh yang demikian, adalah perlu dipastikan bahawa amalan pendidikan boleh diaplikasikan melalui teknologi ini dengan cara yang produktif dan berkesan terutamanya untuk tujuan pembelajaran Bahasa Inggeris sebagai bahasa kedua.
\end{abstract}

Kata kunci: Pembelajaran bahasa berbantukan alat peranti mudahalih; Bahasa Inggeris sebagai bahasa kedua; pelajar Bahasa Inggeris sebagai bahasa kedua; pembelajaran Bahasa Inggeris sebagai bahasa kedua; alat peranti mudahalih

(C) 2017 Penerbit UTM Press. All rights reserved

\subsection{INTRODUCTION}

The impact of ICT in education has been proven in various studies as it is able to make teaching and learning more interesting, motivating as well as meaningful (Chapelle, 2001). Despite using computers, mobile devices are seen to have proven as potential tools in increasing the learning of the language. At present, technology in the language classrooms has been noted for improvement of speaking, writing, listening, and reading skills (Zurita \& Nussbaum, 2004). Thus, technology is essential for enhancing students' achievement, engagement, and overall participation in language learning (Cobb et al., 2010). Furthermore, technology also provides students unlimited access to different resources and tools that facilitate language learning. In English language teaching and learning, Computer-assisted Language Learning (CALL) and Mobile-assisted Language Learning (MALL) are the predominant areas which reflect the adoption of technology to support English language learning. Both CALL and MALL have impacted language acquisitions which distinguish between a modern language classroom and a traditional language classroom in the teaching and learning of English language. Today, mobile technology is 
changing the landscape of language learning and is seen as the next frontier being researched for its potential in enhancing the teaching and learning of English language.

Apparently, the portability of mobile devices is believed to bring new methods that can shape learning styles and pedagogies which could become more personalised and allow learners to learn on the move (Ros i Solé et al., 2010) thus enhancing the English language teaching and learning. The personal nature of mobile phones and their portability suggest that the use of mobile devices for learning may have even bigger potential than e-learning (Vogel et al., 2010). The potential benefits of using mobile devices for learning have been widely touted from a range of purposes which include cost savings, ubiquitous communications, and location-based services (Cheon et al., 2012). The use of mobile devices for learning is becoming widespread and research in this area is urgently needed (Economides \& Grousopoulou 2009). In the past several years, many researchers have investigated the use and effectiveness of mobile devices for second language learning (for example; Stockwell, 2007; Chen \& Chung, 2008) and until today, Mobile-assisted Language Learning (MALL) has continued to attract the interest of several researchers. Despite of that, Mobile-assisted Language Learning (MALL) is still considered one of the new research areas in language teaching and learning (Mandlakayise Patrick Mthethwa, 2014).

For learning English as second language, mobile phone is a good media for drills \& practices for vocabulary, English expressions, and practices in English communication (Kwon \& Eun, 2010). Since, mobile technology could act as an efficient mediator for enhancing English language learning; Mobile-assisted Language Learning (MALL) is proposed to support students' learning needs as well as achieving the target needs of their English language courses. In the past few years, a surge in the use of mobile devices as educational tools has led to an increase number of educational institutional exploring the possibilities of using these ubiquitous devices by their students, both within the classroom and beyond (Engel \& Green, 2011; Messinger, 2011). While the decisions are made, technology continues to impact students' life inside and outside the classrooms to an extent that they use technology to enhance their classroom learning experiences. The following sections discuss the definition of Mobile-assisted Language Learning (MALL) and various research done related to MALL, the affordances and the constraints of the use of MALL among ESL learners.

\subsection{MOBILE-ASSISTED LANGUAGE LEARNING (MALL): ITS DEFINITION AND PREVIOUS STUDIES}

The history of MALL began with a research by Twarog and Pereszlenyi-Pinter in the 80s which looked at telephone assisted language study. They used telephones to provide distant language learners with assistance and feedback (Twarog \& Preszlenyi Pinter, 1988). Mobile-assisted Language Learning (MALL) has developed over the past decade as a field within its own right, with an increasing number of articles that examine various mobile devices used in environments both inside and outside of formal language learning. KukulskaHulme \& Shield (2008), in an overview of Mobile-assisted Language Learning, define MALL as formal or informal learning mediated via handheld devices which are potentially available for use anytime, anywhere. Handheld devices include mobile phones and tablet computers with Internet capability and other devices without Internet access such as electronic dictionaries, MP3 players and game players. There has been a surprisingly large amount of research published over the past two decades that has seen the field develop along with the enormous steps forward that have taken place in MALL.

Apparently, there have been trials of Mobile-assisted Language Learning (MALL) applications since 2001 (e.g. Stanford Learning Lab, 2001). Chinnery (2006) and Kukulska-Hulme \& Shield (2008) both provide reviews of many MALL developments since then, and although there have been some interesting uses of multimedia on PDAs and iPods (e.g. Thornton \& Houser, 2003; Garcia Cabrere, 2002; Belanger, 2005; Kukulska-Hulme, 2005), the focus has generally been on delivering basic features such as vocabulary learning and quiz drills in text format over mobile phones.

Valarmathi (2011) stated that Mobile-assisted Language Learning (MALL) describes an approach to language learning that is assisted or enhanced through the use of a handheld mobile device. MALL is a subset of both Mobile Learning (m-learning) and Computer-assisted language learning (CALL). MALL is language learning using mobile devices such as:

a. Cell (mobile) phones and smart phones (including the iPhone or iPad.)

b. MP3 or MP4 players (e.g. iPods)

c. Personal Digital Assistants (PDAs) (e.g. Palm Pilot, Blackberry, etc)

With MALL, the advantage is that students are able to access language learning materials and to communicate with their teachers and peers at anytime, anywhere. Thornton \& Houser (2005) conducted several innovative projects involving the use of mobile devices particularly mobile phones which one of them focused on the teaching of the English Language specifically on vocabulary acquisition. Their study found that the group who uses SMS learnt twice as many words as compare to those who study using the web. The group has also improved their score twice as much as compared to those who studied using papers. Learners attitudes were also found to have improved in the sense that they prefer to receive the SMS instructions and the believe teaching through SMS is a valuable method. The findings of the study Thornton \& Houser (2005) was supported by Levy and Kennedy (2005) which then conducted a similar study with their Italian learners. They send vocabulary words and idioms, definitions and example sentences via sms.

Another study that dwells with vocabulary learning was conducted by Chen and Chung (2008). Their study presented a vocabulary learning system based on Item Response Theory and learning memory cycle. This was translated into recommending as set of vocabulary lists according to individual ability and was delivered through a PDA. The results indicated an increase in vocabulary acquisition and increased learning performance. Chen and Chung (2008) believed that the success was due to the effective and flexible learning mode. Additionally, there was also an attempt by Kiernan \& Aizawa (2004) to look at the use of mobile devices on task based learning. They believed that task based learning is the best way to promote the acquisition of language. Similar to Thornton and Houser (2005), they divided the students into three groups: PC email users, mobile users and face-to-face speaking users. Their study concluded that although fewer words were used by the mobile users, they were able to communicate effectively.

Other than that, there were also a number of attempts to use specific functions of mobile devices in language teaching and learning environments. Gromik (2012), for example, required Japanese learners to use the video recording function of their mobile phones to produce short English monologues. He found that the learners were able to make increasingly longer videos over time. In another study, Sandberg, Maris \& de Geus (2011) provided young Dutch learners with mobile phones equipped with GPS capabilities in order to help them learn English vocabulary. The learners negotiated their way around a zoo and completed a number of games based on the different 
animals around the zoo. Rivers (2009) required Japanese learners of English to scan Quick Response (QR) codes that were posted around the university in order to complete several information exchange tasks. QR codes are graphics that enable the phones to automatically link to online information.

\subsection{POTENTIAL AFFORDANCES FOR USING MOBILE-ASSISTED LANGUAGE LEARNING (MALL)}

Mobile technology has become an important tool in the teaching and learning process. Studies have shown that technologies especially the use of mobile devices does bring positive impacts in improving English language proficiency. Chinnery (2006) pointed out those mobile devices such as mobile phones, PDAs and iPods are all possible tools for enhancing language learning. There are studies which have successfully used mobile devices for teaching pronunciations and listening skills (e.g. Uther et al. 2005) and also for teaching English tenses to ESL learners such as the one conducted by Bull et al. (2005) which has shown significant positive outcomes. Chang (2005) claimed that mobile devices are suitable for vocabulary learning and that the ubiquitous usage of mobile phones among college students also makes it a practical choice for research on mobile learning.

Mobile phones have the prospect of supporting the subject of English Language and would bring added value. Many innovative applications incorporating mobile technology have also been attempted in the subject of foreign language learning and English language learning (Kukulska-Hulme \& Traxler, 2005). Various studies (e.g. Ally, 2009; Dias, 2002; Dickey, 2001) have shown an explosion of interest in using mobile devices for English language teaching and learning. Mobile devices have some characteristics which allow them to be suitable tools for modern education especially in terms of providing exploring and sharing learning contents. The characteristics can be summarised as portability, functionality, ubiquity, utility and connectivity (Pachler et al., 2010). These characteristics have definitely a lot to offer for learners of English as Second Language (ESL).

Evidently, studies have shown that MALL allows learners to access to the desired learning materials (e.g. Dickey, 2001). This could accommodate to individualised learning where students are free to choose their own learning activities according to their learning pace. As a result, when students are provided with individualised learning, they are able to think critically and aware of their capabilities (Sariah $e t$ al., 2014). It is also very important in ESL learning that students perceived the learner fit criterion. Learner fit refers to the amount of opportunity for engagement with language under appropriate conditions given learner characteristics. Learner fit reflects the ways in which individuals differ such as age, learning style, and stages of development (Pienemann, 1985; cited in Chapelle et al., 2005). Wi-Fi technology in mobile devices allows learners to access supplementary learning materials and teachers can also use mobile devices to communicate and send learning materials to their learners at anytime convenient to them (Ally, 2009). Yedla (2013) states that the advance of technology could enhance self-learning and thus may encourage the students to continue the learning process on their own in English language for their future. Additionally, MALL applications can facilitate learners in interacting with others collaboratively anytime and anywhere.

Kloper, Squire, and Jenkins (2002) discussed five unique educational attributes of mobile devices which could reflect the use of Mobile-assisted Language Learning (MALL) which are;

- Portability: the mobile devices allow movability

- Social interactivity: the mobile devices facilitate and enhance the communication between users

- Context sensitivity: the mobile devices provide real data in learners' location, environment and time

- Connectivity: the devices can be connected to each other or a shared network

- Individually: the devices allow individual learning.

The unique educational attributes of mobile devices discussed by Kloper et al. (2002) are seen as the affordances that what Mobileassisted Language Learning (MALL) has to offer for ESL learners. Apart from that, mobile devices are designed to provide a lot of functionalities that can be used for supporting and enhancing teaching and learning methods, like messaging, games, internet access and multimedia convergence (Khaddage et al., 2009).

Apart from that, due to its portability characteristic, the use of mobile devices removes temporal and spatial limitations of learning and allows students and teachers to organise their time more effectively by extending access to course related information, communication, and collaboration (Naismith et al., 2004). Continual connectivity to information encourages more flexible access and engagement in learning and knowledge sharing (Alexander, 2004; Kukulska-Hulme \& Traxler, 2007). This can extend into more contextual situations for students by enabling them immediate communication and dissemination of information (e.g., text, email, video, discussion boards) and access to information sources (Motiwalla, 2005; Sharples, 2000).

Nevertheless, the most important characteristic in the use of mobile devices for learning ESL is mobility, which gives the students freedom to practice learning anytime, anywhere and maintains contact between students and lecturers outside the class (Wang \& Ryu, 2009). Using their mobile devices they can extend learning environment beyond the classroom setting. Learning through mobile phones outside the classroom has the advantage of better exploiting the learner's free time; even the students on the move can improve their learning skills (Kukulska, 2009). Mobile devices provide learning materials with movable, flexible and independently controlled environments (Juniu, 2002). Mobility adds new options to the activities that can be enhanced regarding to the portability and the features of mobile devices (Naismith et al., 2004).

However, despite of the potential affordances, issues have been raised continuously on the constraints which are considered barriers in implementing the use of MALL. The following section discusses the constraints that ESL learners could be facing in using MALL for learning English language.

\subsection{CONSTRAINTS FOR USING MOBILE-ASSISTED LANGUAGE LEARNING (MALL) AMONG ESL LEARNERS}

Despite unique advantages, there are some constraints that limit the capability of mobile devices. In the aspect of usability, screen size, battery life, storage, and slow downloading are several constraints related to the use of mobile devices for learning (e.g., Georgiev et al., 
2004; Corlett et al., 2005; Franklin et al., 2007). For example, some studies identify usability issues like small keyboards as a constraint to mobile learning (Sharples \& Jeffery, 2002; Wentzel et al., 2005). Small screen size can cause viewing difficulties, eyestrain, or be difficult for vision impaired individuals. In addition, web pages are not always designed for small screens (Alexander, 2004; Bachfischer et al., 2008). Apart from that, limited storage and memory, and document editing capabilities may also limit mobile academic activities (Shudong \& Higgins, 2005). Small keyboard and screen size is not appropriate for document editing (Shudong \& Higgins, 2005). This indicates that student learning activities via using mobile devices with limited typing requirements may be ideal (Huang, 2014).

Furthermore, limited availability of broadband wireless access (Bachfischer et al., 2008) may also hinder the Mobile-assisted Language Learning (MALL) implementation. To ensure network connectivity, a pure connection and pure mobility mode for the mobile device should be considered so that it can download and store what is needed for most of the learning process and be able to function with minimal or no connection for long periods of time (Orr, 2010). Multitasking sometimes also causes mobile learner's distraction, which consequently compromises the retaining of learning contents (Dolittle et al., 2009). For example, using mobile devices in class might disturb students' concentration and impede the learning process.

The cost of mobile devices and services is also another consideration. Some studies identified both the cost imposed by telecommunications for access and mobile devices to be primary cost barriers for students (e.g., DuVall et al., 2007; Savill-Smith \& Kent, 2003). Apart from that, some studies (Wang et al., 2009; Park, 2011) indicated that students are more likely to use mobile devices for entertainment uses such as listening to music, texting other friends and checking social networks rather than for educational purposes. Therefore, it is important to make the students aware of the advantages of using mobile device for learning particularly for English as Second Language (ESL) learning.

Pedagogically, some aspects should be taken in consideration while mobile devices integrated in learning (Wang et al., 2009; Park, 2011) especially for English as Second Language (ESL) Learners. Resources may also become another constraint. Without adequate resources, both in the form of materials and human support, the integration of ICT in class instruction cannot be carried out properly even though all the other conditions are present (Termit \& Ganisha, 2014).

\subsection{SUGGESTIONS FOR PEDAGOGICAL IMPLICATIONS}

Based on the discussion in the previous sections, it could be concluded that Mobile-assisted Language Learning (MALL) could bring more affordances than constraints. It is however that the constraints should be taken into consideration in order to ensure successful implementation or employment of MALL among ESL learners in order to enhance their English language learning. The support education institutions via administration, management and lecturers are important in promoting the use of MALL. Overall, efforts to employ MALL need to be holistic. Training and technical support are important in encouraging ESL learners to use MALL. It is thus very important for the education institutions in all phases of MALL deployment (pre and post implementation) to stay committed to the success of using mobile devices for learning English language and to show that commitment to students. Additionally, customized or personalized services must be sought, as students have indicated a desire for personalization.

ESL lecturers can also promote students' intention for using MALL by adding value to their traditional teaching methods using MALL. However, it is to be realized that ESL lecturers need to be familiar with this new technology and be ready to be involved in the implementation plans. There is a need to motivate polytechnic ESL lecturers, increase their awareness of MALL and provide them with sufficient training. The results also indicated that polytechnics need to develop strategic plans and provide guidelines considering students' intention and finally acceptance in order to include all critical success factors for the sustainable deployment of MALL in order to enhance English language learning.

Above all, there is still a need for guidance through the vast amount of information and those materials to be organised around pedagogical tasks. Accordingly, it is essential to provide learning and technology help options which include access to peers and experts and task-specific help for learning activities. This encourages scaffolding which is derived from communication with others as well as mobile access to a choice of resources is critical; however, the facilitator should allow some of the control and empower the learners to accept more responsibility for learning.

As a conclusion, leveraged by mobile technology, the flexibility within MALL in English language learning can be further enhanced. Students may use various functions of the mobile device such as to record their own notes in text and audio, take photos, as well as creating and publishing writing materials using mobile devices. This allows for English language to be learnt in a more meaningful and authentic environment integrating all four language skills which are listening, speaking, reading and writing.

\subsection{CONCLUSION}

Above all, it was a challenging issue to cover learning tasks by using a mobile device particularly in learning English as Second Language. It is important that the efforts to employ Mobile-assisted Language Learning (MALL) need to be holistic. Mobile devices have rapidly developed to become tools for learning the languages thus introduces the use of Mobile-assisted Language Learning (MALL) for ESL learners. MALL has played a significant role to support language learning due to its salient features of mobile device. Undeniably, mobile devices which are popular among students are motivational tools to be used in education and various learning activities as many researches have shown the positive outcomes. These could be seen as an indicator that the utilization of mobile phones in teaching and learning of ESL would be an effective approach in overcoming the difficulties faced by academicians in motivating students to learn English language as well as enhancing their learning experience and eventually increase their proficiency. Hence, we should admit that mobile devices are finding their way into classrooms in the student's pockets, and we have to ensure that educational practice can include this mobie technology in effective and productive ways. 


\section{References}

Alexander, B. (2004). Going nomadic: Mobile learning in higher education. EDUCAUSE Review, 39(5), 28-35.

Ally, M. (Ed.). (2009). Mobile Learning: Transforming the delivery of education and training. Athabasca, Canada: Athabasca University Press. Available at: <http://www.aupress.ca/books/120155/ebook/99Z_Mohamed_Ally_2009-MobileLearning.pdf> [April 2014].

Bachfischer, A., Dyson, L., \& Litchfield, A. (2008). Mobile Learning And Student Perspectives: A Reality Check! In Proceedings of 7th International Conference on Mobile Business, 287-295.

Belanger, Y. (2005). Duke University iPod First Year Experience Final Evaluation Report. http://cit.duke.edu/pdf/ipod_initiative_04_05.pdf [June 2014].

Chang, M. M. (2005). Applying Self-Regulated Learning Strategies In A Web-Based Instruction: An Investigation Of Motivation Perception. Computer Assisted Language Learning, 18, $217-230$

Chapelle, C., Jamieson, J. \& Preiss, S. (2005). Call Evaluation By Developers, A Teacher, And Students. https://calico.org/a-133-CALL\%20Evaluation\%20 by\%20Developers \% 20 a\% 20Teacher \%20and\%20Students.html [October 2013]

Chapelle, C. A. (2001). Computer Applications in Second Language Acquisition. Foundations For Teaching, Testing And Research. Cambridge, UK: Cambridge University Press.

Chen, C. M. \& Chung, C. J. (2008). Personalized mobile English Vocabulary Learning System Based On Item Response Theory And Learning Memory Cycle. Computers \& Education, 51(2), 624-645. http://dx.doi.org/10.1016/j.compedu.2007.06.011 [January 2014].

Cheon, J., Lee, S., Crooks, S. M., \& Song, J. (2012). An Investigation Of Mobile Learning Readiness In Higher Education Based On The Theory Of Planned Behavior. Computers \& Education, 59(3), 1054-1064. doi:10.1016/j.compedu.2012.04.015

Chinnery, M. G. (2006). Emerging Technologies Going to the MALL: Mobile Assisted Language Learning. Language Learning \& Technology, 10 (1), 9-16.

Cobb, S., Heaney, R., Corcoran, O., \& Henderson-Begg, S. (2010). Using Mobile Phones To Increase Classroom Interaction. Journal of Educational Multimedia and Hypermedia, 19(2), 147-157.

Corlett, D., Sharples, M., Bull, S., and Tony, C. (2005). Evaluation Of A Mobile Learning Organizer For University Students. Journal of Computer Assisted Learning, $21(3), 162-170$

Dias, J. (2002) CELL Phones In The Classroom: Boon Or Bane? Calling Japan, 10(2). http://jaltcall.org/cjo/101.pdf

Dickey, R. J. (2001). Make it a Conference Call: An English Conversation Course By Telephone in South Korea. In L.E. Henrichsen (Ed.), Distance-Learning Programs, 51-60. Alexandria, VA: Teachers of English to Speakers of Other Languages, Inc.

Dolittle, P., Lusk, D., Byrd, C., and G., M. (2009). iPods as Mobile Multimedia Learning Environments: Individual Differences And Instructional Design. In Ryu, H. and Parsons, D., (Eds.), Innovative Mobile Learning: Technique And Technologies, 83-101. Information Science Reference, Hershey, PA.

DuVall, J. B., Powell, M. R., Hodge, E., \& Ellis, M. (2007). Text Messaging To Improve Social Presence In Online Learning. Educause Quarterly, 3, 24-28.

Economides, A. A., \& Grousopoulou, A. (2009). Students' Thoughts About The Importance And Costs Of Their Mobile Devices' Features And Services, 26, 57-84. doi:10.1016/j.tele.2008.01.001

Engel, G., \& Green, T. (2011). Cell Phones In The Classroom: Are We Dialing Up Disaster? TechTrends, 55(2), 39-45.

Franklin, T., Sexton, C, Lu, Y., \& Ma, H. (2007). PDAs in Teacher Education: A Case Study Examining Mobile Technology Integration. Journal of Technology and Teacher Education, 15(1), 39-57. Retrieved September 23, 2007, from the WilsonSelectPlus database.

Garcia Cabrere, J. C. (2002). Tele-enREDando.Com: Multimedia WEB-CALL Software For Mobile Phones. International Journal of English Studies, 2(1), 167-178.

Gromik, N. (2012). Cell Phone Video Recording Feature As A Language Learning Tool: A Case Study. Computers \& Education, 58(1), $223-230$.

Huang, Y. (2014). Empirical Analysis on Factors Impacting Mobile Learning Acceptance in Higher Engineering Education.

Juniu, S. (2002). Implementing Handheld Computing Technology in Physical Education. Journal of Physical Education, Recreation \& Dance, 73(3), 43-48.

Khaddage, F., Lanham, E. \& Zhow, W. (2009). A Mobile Learning Model for Universities: Re-Blending The Current Learning Environment. International Journal of Interactive Mobile Technologies, 3(1), 18-23.

Kiernan, P. J., \& Aizawa, K. (2004). Cell Phones In Task Based Learning - Are Cell Phones Useful Language Learning Tools? ReCALL, 16(01), 71-84.

Kloper, E., Squire, K. \& Jenkins, H. (2002). Environmental Detectives: PDAs as a Window Into A Virtual Simulated World. In Proceedings for IEEE International Workshop on Wireless and Mobile Technologies in Education, 30 August, 95-98.

Kukulska-Hulme, A. (2005). The Mobile Language Learner-Now And In The Future. Fran Vision till Praktik. Language Learning Symposium conducted at Umea University in Sweden. http://www2.humlab.umu.se/symposium2005/program.htm. [October 2013].

Kukulska-Hulme, A. (2009). Will Mobile Learning Change Language Learning? ReCALL, 21(02), 157-165.

Kukulska-Hulme, A., \& Traxler, J. (2007). Learning Design with Mobile and Wireless Technologies. In H. Beetham, \& R. Sharpe (Eds.), Rethinking Pedagogy for the Digital Age: Designing and Delivering E-learning, Routledge, London.

Kukulska-Hulme, A., Shield, L. (2008). An Overview Of Mobile Assisted Language Learning: From Content Delivery To Supported Collaboration And Interaction. $\operatorname{ReCALL}, 20(3), 271-289$.

Kwon, S., \& Eun, J. (2010). Design Principles Of M-Learning for ESL, 2, 1884-1889. doi:10.1016/j.sbspro.2010.03.1003

Levy, M., \& Kennedy, C. (2005). Learning Italian via mobile SMS. In A. Kukulska- Hulme \& J. Traxler (Eds.), Mobile learning: A Handbook For Educators And Trainers, London: Routledge. pp. 76-83.

Mandlakayise Patrick Mthethwa. (2014). The Utility Of Mobile-Assisted Language Learning (Mall): ESL Students' Beliefs About New Literacy In Swaziland. A Dissertation Submitted in Partial Fulfillment of the Requirements for PhD. University Swaziland

Messinger, J. (2011). M-learning: An Exploration Of The Attitudes And Perceptions Of High School Students Versus Teachers Regarding The Current And Future Use Of Mobile Devices For Learning. (Pepperdine University). ProQuest Dissertations and Theses, 227. http://seareh.proquest.eom/docview/914201229?accountid=26967. [July 2014]

Naismith, L., Lonsdale, P., Vavoula, G., \& Sharples, M. (2004). Literature Review In Mobile Technology And Learning. Future Lab Report 11. http://www. futurelab.org.uk/resources/documents/lit_reviews/Mobile_Review.pdf. [December 2013]

Orr, G. (2010). A Review Of Literature In Mobile Learning: Affordances And Constraints. In Proceedings of 6th IEEE International Conference on Wireless, Mobile and Ubiquitous Technologies in Education, 107-111, Kaohsiung, Taiwan.

Pachler, N., Bachmair, B., Cook, J. (2010). Mobile Learning (Structures, Agency, Practices). New York: Springer.

Park, Y. (2011). A Pedagogical Framework for Mobile Learning: Categorizing Educational Applications Of Mobile Technologies Into Four Types. International Review of Research in Open and Distance Learning, 12(2), 78-102.

Rivers, D. (2009). Utilizing the Quick Response (QR) Code Within a Japanese EFL Environment. The JALT CALL Journal, 5(2), 15-28.

Ros i Solé, C., Calic, J., \& Neijmann, D. (2010). A Social And Self-Reflective Approach to MALL. ReCALL, 22(01), 39-52.

Roschelle, J., Sharpies, M., \& Chan, T. W. (2005). Introduction To The Special Issue On Wireless And Mobile Technologies In Education. Journal of Computer Assisted Learning, 2(1), 159-161. doi: 10.1111/j. 1365-2729.2005.00123.

Sandberg, J., Maris, M., De Geus, K. (2011). Mobile English Learning: An Evidence-Based Study With Fifth Graders. Computers and Education, 57, $1334-1347$.

Sariah, S., Hassan, S., \& Rajab, M. (2014). Social Sciences \& Humanities Science Teaching Styles and Student Intrinsic Motivation: Validating a Structural Model, $22(1), 335-344$

Savill-Smith, C. and Kent, P. (2003). The Use Of Palmtop Computers For Learning. Retrieved Dec. 4th, 2012, from http://www.m-learning.org/docs/the_use_of palmtop_computers_for_learning_sept03.pdf.

Sharples, M. (2000). The Design Of Personal Mobile Technologies For Lifelong Learning. Computers \& Education, 34:177-193.

Sharples, M. (2006). Big Issues In Mobile Learning: Report Of A Workshop By The Kaleidoscope Network Of Excellence Mobile Learning Initiative. Nottingham: University of Nottingham.

Sharples, M. \& Jeffery, N. (2002). Next-generation Paradigms And Interfaces For Technology Supported Learning In A Mobile Environment Exploring The Potential Of Ambient Intelligence. MOBIlearn. 
Shudong, W. \& Higgins, M. (2006). Limitations of Mobile Phone Learning. The JALT CALL Journal, 2(1), 3-14.

Stockwell, G. (2007). Vocabulary On The Move: Investigating An Intelligent Mobile-Based Vocabulary Tutor. Computer Assisted Language Learning, 20(4), 365383.

Termit, K. \& Ganisha, V. (2014). Social Sciences \& Humanities Teachers' Uptake on ICT Integration in Teaching and Learning - A Case of Malaysian Teachers, $22(4), 1163-1172$.

Thornton, P. \& Houser, C. (2005). Using Mobile Phones In English Education in Japan. Journal of Computer Assisted Learning, 21(3), 217-228. http://dx.doi.org/10.1111/j.1365-2729.2005.00129.x [April 2014]

Twarog, M. \& Pereszlenyi-Pinter. 1988. Telephone-Assisted Language Study and Ohio University: A report. The Modern Language Journal, 72, 426-434

Uther, M., Zipetria, I., Uther, J., \& Singh, P. (2005). Mobile adaptive CALL (MAC): A Case Study In Developing A Mobile Learning Application For Speech/Audio Language Training. Wireless and Mobile Technologies in Education (IEEE). Tokushima, Japan: IEEE Computer Society.

Valarmathi, K. E. (2011). Mobile Assisted Language Learning. Journal of Technology for ELT. 1(2).

Venkatesh, V., Morris, M., Davis, G., and Davis, F. (2003). User Acceptance Of Information Technology: Toward A Unified View. MIS Quarterly, 27(3), 425-478.

Vogel, B., Spikol, D., Kurti, A., \& Milrad, M. (2010). Integrating Mobile, Web, And Sensory Technologies To Support Inquiry-Based Science Learning, Proceeding of the 6th IEEE International Conference on Wireless, Mobile, and Ubiquitous Technologies in Education, Los Alamitos, CA: IEEE Computer Society, 65-72.

Wang, P. and Ryu, H. (2009). Not SMS, but Mobile Quizzes: Designing a Mobile Learning Application For University Students. International Journal of Mobile and Organisation, 3(4), 351-365.

Wang, Y. S., Wu, M. C., \& Wang, H. Y. (2009). Investigating the Determinants and Age and Gender Differences in the Acceptance of Mobile Learning. British Journal of Educational Technology, 40(1), 92-118. doi: 10.1111/j.1467- 8535.2007.00809.

Wentzel, P., Van Lammeren, R., Molendijk, M., de Bruin, S., \& Wagtendonk, A. (2005). Using Mobile Technology To Enhance Students' Educational Experiences. Educause Quarterly, ECAR Case Study 2ECAR Case Study, (2), 1-18.

Yedla, S. (2013). MALL (Mobile Assisted Language Learning): A Paradise for English Language Learners. Journal of English Language \& Translation Studies,1(2), 91-99.

Zurita, G., \& Nussbaum, M. (2004). Computer Supported Collaborative Learning Using Wirelessly Interconnected Handheld Computers. Computers and Education, $42(3), 289-314$ 